Este es justamente uno de los grandes logros del volumen: la integración de alegatos de tipo ético, moral o simplemente evaluativo sin que se produzca un corte substancial respecto a la argumentación estrictamente académica, basada en la aportación de datos pertinentes y el análisis crítico de las obras. Así, pues, leemos posicionamientos inequívocos, ubicados a menudo en la sección de los diagnósticos. En general, queda claro que la autora rechaza — razonadamente — "la cosmovisión judeocristiana y platónica como único modo de contemplar el mundo [...] occidental" (p. 191), postulando que "la hibridación, el mestizaje y el equilibrio en la interrelación humano-máquina son el estado utópico hacia el que proyectarnos, evitando, eso sí, radicalismos y profecías edificantes como las proclamadas por algunos poshumanistas radicales que pretenden intercambiar el binomio humano-máquina, por el de máquina-máquina" (p. 132). Por otro lado, tal vez podría puntualizarse que hubiera sido positivo añadir alguna referencia al estudio seminal de Sontag, Illness as Metaphor (1978), en el apartado que trata acerca de la metástasis como término empleado a la hora de interpretar una de las patologías de la realidad virtual mencionadas; o aludir a estudios generales sobre teoría de la ciencia ficción, que habrían podido complementar alguno de los análisis presentados, por ejemplo la también hispánica Teoría de la literatura de ciencia ficción: poética y retórica de lo prospectivo (2010), de Fernando Ángel Moreno. Sin embargo, ninguna de estas ausencias empaña la brillantez y la completitud argumentativa del estudio, puesto que la autora echa mano de una larga lista bibliográfica que, además, contiene en su mayoría obras específicamente referidas a los temas tratados, además de libros de cabecera en diferentes campos de lo investigado.

\title{
Adam Mazurkiewicz
}

Uniwersytet Łódzki

\section{Kompendium nie tylko dla pasjonatów gier fabularnych}

DOI: $10.19195 / 0867-7441.22 .24$

Recenzja: Gry fabularne. Kultura — praktyki - konteksty, red. Robert Dudziński, Anna Wróblewska, Stowarzyszenie Badaczy Popkultury i Edukacji Popkulturowej „Trickster”, Wrocław 2016, ss. 120.

Słowa kluczowe: gry fabularne, system rozrywkowy, antropologia, uniwersum, nowelizacja gier

Keywords: role-playing games, system of entertainment, anthropology, the Universe, novelization of games

Najnowsza pozycja, która pojawiła się na stronie Stowarzyszenia Badaczy Popkultury i Edukacji Popkulturowej „Trickster”, została poświęcona grom fabu- 
larnym. Decyzja, by to właśnie owo medium kultury objąć namysłem badawczym, jest ze wszech miar słuszna. Biorąc pod uwagę ich rosnącą popularność oraz ekspansywny rozwój utrzymanych w różnorodnej poetyce systemów RPG, konieczne stało się opracowanie - choćby wstępnej, o charakterze rekonesansu — syntezy, która zbierałaby, rozproszone dotychczas na łamach różnych pism i na kartach prac zbiorowych, ustalenia badaczy. Tym bardziej że ambicją redaktorów zbioru było — jak sami deklarują we Wstępie — nie tyko ukazanie fenomenu gier narracyjnych z różnorodnej perspektywy, m.in. socjologicznej, psychologicznej, ludologicznej (s. 7-8), ale i osadzenie ich w szerszym kontekście „kultury gier”. Stąd pozornie nieoczywista decyzja, by część szkiców poświęcić problematyce związanej z grami komputerowymi oraz by omówić LARP jako osobny tekst kultury; nie zabrakło też miejsca na studium nad zjawiskiem nowelizacji gier. Lektura poświęconego temu zagadnieniu szkicu Olafa Pajączkowskiego uświadamia, do jakiego stopnia współczesny system rozrywkowy tworzy intermedialne uniwersa ${ }^{1}$.

Tym, co łączy poszczególne szkice, jest przekonanie ich autorów o potrzebie wypracowania języka dyskursu i terminologii, umożliwiającej sprawne definiowanie omawianych zagadnień; daleko przy tym badaczom do „nadprodukcji terminologicznej" i manieryzmu, nakazującego podążać za modami intelektualnymi (szczególnie popularną współcześnie antropologizacją nauki²). Na uwagę zasługuje też akrybia badaczy, przejawiająca się choćby w datowaniu poszczególnych tekstów kultury, dzięki czemu odbiorca nie ma poczucia chaosu, wynikającego z nadmiernej liczby gier stanowiących podstawę bibliografii podmiotowej. Jest to istotne zwłaszcza jeśli - jak w wypadku szkicu Michała Wolskiego — autor dąży do syntetycznego obrazu zagadnienia, pozwala bowiem czytelnikowi odtworzyć chronologię publikacji kolejnych gier oraz relacje czasowe, jakie potencjalnie mogą zachodzić pomiędzy nimi.

Całość tomu dopełnia zestawienie bibliograficzne rodzimych prac poświęconych grom fabularnym, którego rangę trudno przecenić. Pełni ono przynajmniej dwie podstawowe funkcje: nie tylko gromadzi i systematyzuje informacje na temat opracowań dotyczących gier fabularnych, ale też stanowi doskonały punkt wyjścia poszukiwań własnych czytelnika. W tym sensie autorzy zestawienia kon-

${ }^{1}$ Zob. O. Pajączkowski, Artyzm czy robota na zlecenie? Wolność twórcza autorów książek osadzonych $w$ światach PRG (na przyktadzie powieści z cyklu „Dragonlance” $i$,Forgotten Realms"), [w:] Gry fabularne. Kultura - praktyki - konteksty, red. R. Dudziński, A. Wróblewska, Wrocław 2016, s. 32-47.

${ }^{2} \mathrm{Na}$ konsekwencje tendencji do antropologizacji nauki zwracał m.in. uwagę Tarzycjusz Buliński, akcentując nie tylko pozytywy tego procesu, ale i negatywne jego aspekty. Zob. T. Buliński, Czym jest antropologizacja nauk?, [w:] Zanikające granice. Antropologizacja nauki i jej dyskursów, red. A. Pomieciński, S. Sikora, Poznań 2009, s. 276-277. Z kolei konsekwencje nieodłącznej od antropologizacji „dyfuzji terminologicznej” omawia Monika Banaś. Zob. M. Banaś, Transgresja i dyfuzja - czyli o tym dlaczego nauki społeczne i humanistyczne siegaja do terminologii nauk przyrodniczych, „Kultura - Historia - Globalizacja” 2013, nr 14, http://www.khg.uni.wroc.pl/ files/1_\%20KHG_14_banas_t.pdf, dostęp: 9.08.2016. 
tynuują prace zapoczątkowane przez Krystynę Walc, sukcesywnie ogłaszającą na łamach „Literatury i Kultury Popularnej” zestawienia bibliografii przedmiotowej prac, w których podjęta została problematyka związana z literaturą i kulturą popularną ${ }^{3}$. Ambicją Stanisława Krawczyka i Roberta Dudzińskiego było nie tylko dotarcie do wszystkich (niezależnie od wartości merytorycznej) opracowań poświęconych grom fabularnym, ale i weryfikacja dostępności owych szkiców w zasobach sieci internetowej. Dziwi jednak decyzja autorów, by podzielić całość zestawienia na dwie części, obejmujące - kolejno - teksty wydane do roku 2011 (de facto w okresie 1997-2011) i w latach 2012-2015. Nieco zaskakujący jest też brak pracy Rafała Kochanowicza Fabularyzowane gry komputerowe w przestrzeni humanistycznej. Analizy, interpretacje $i$ wnioski z pogranicza poety$k i$, aksjologii, dydaktyki literatury (Poznań 2012). Do pewnego stopnia nieobecność ta usprawiedliwiona jest charakterem rozprawy Kochanowicza, tematycznie przekraczającej problematykę narracyjnych gier fabularnych, jakkolwiek znaleźć w niej można passus omawiający i to zagadnienie ${ }^{4}$. Z niewyjaśnionych jednakże przez redaktorów tomu powodów w końcowym zestawieniu bibliograficznym nie pojawiły się prace poświęcone narracyjnym grom fabularnym, które zostały przywołane w bibliografiach bezpośrednio pod artykułami. Zrozumiałe jest, że redaktorzy nie chcieli dublować zapisów. Czy nie należało w tej sytuacji zrezygnować raczej z owych zestawień na rzecz pełnej bibliografii przedmiotowej?

Niemniej, mimo naszkicowanych tu ułomności koncepcyjnych, inicjatywa redaktorów tomu, by uzupełnić go zestawieniami bibliograficznymi, wskazuje na kontynuację tej dobrej i potrzebnej tradycji filologicznej, zapoczątkowanej przez najstarszy krajowy rocznik (wychodzący nieprzerwanie od 1991), poświęcony zagadnieniom literatury i kultury popularnej — „Literaturę i Kulturę Popularną”. Jedynie bowiem $\mathrm{w}$ ten sposób tworzy się międzypokoleniowy dialog badaczy, przejawiający się m.in. w powstawaniu „szkół” — w tym „wrocławskiej szkoły badania popkultury".

${ }^{3}$ Zob. K. Walc, Literatura i kultura popularna - bibliografia przedmiotowa za rok 2008, „Literatura i Kultura Popularna” XVI, Wrocław 2010, s. 151-168; eadem, Literatura i kultura popularna. Bibliografia przedmiotowa za rok 2009 (z uzupetnieniami za rok 2008), „Literatura i Kultura Popularna" XVII, Wrocław 2011, s. 199-213.

${ }^{4}$ Zob. R. Kochanowicz, Fabularyzowane gry komputerowe w przestrzeni humanistycznej. Analizy, interpretacje $i$ wnioski z pogranicza poetyki, aksjologii, dydaktyki literatury, wyd. 2, Poznań 2013, s. 30-50. 